\title{
Sağlık Yönetimi ve İnsan Kaynakları Yönetimi Öğrencilerinin Covid-19'un Kontrolüne ve Aşısına Yönelik Algı ve Tutumlarının Değerlendirilmesi
}

\author{
Evaluation of Health Management and Human Resources Management Students' Perceptions and Attitudes \\ towards the Control and Vaccine of Covid-19
}

\section{Yeter DEMIR USLU ${ }^{1}$, Emre YILMAZ2, Umutcan ALTUN ${ }^{3}$}

\begin{abstract}
Öz
$\mathrm{Bu}$ çalışmanın amacı üniversite öğrencilerinin Covid-19'un kontrolüne ve aşısına yönelik alg1 ve tutumlarının incelenmesidir. Ayrıca öğrencilerin bölümlerine, sağlık eğitimi alma durumlarına ve çevresinde Covid-19 vakası olma durumlarına göre de alg1 ve tutumları arasındaki farklılıklar incelenmiştir. Araştırmanın evrenini bir vakıf üniversitesindeki 730 öğrenci; örneklemini ise \%95 güven aralığ1 esas alınarak 304 öğrenci oluşturmaktadır. Değişkenler arasındaki farklılıklar bağımsız örneklem $\mathrm{T}$ testi ile analiz edilmiştir. Araştırma bulgularında, öğrencilerin aşıya yönelik tutum ortalamaları $3,09 \pm 0,68$; kontrol alg1 ortalamaları ise $2,82 \pm 0,53$ olarak tespit edilmiştir. Öğrencilerin bölümlerine ve sağllk eğitimi alma durumlarına göre Covid-19 pandemisine yönelik kontrol algıları ve Covid-19 aşısına yönelik olumlu tutum alt boyutunun anlamlı olarak farklılık gösterdiği $(\mathrm{p}<0,05)$; olumsuz tutum alt boyutuna ve çevresinde Covid-19 tanısı konulan hasta olma durumuna göre ise istatistiksel olarak anlamlı bir farklılık göstermediği tespit edilmiştir. $(\mathrm{p}>0,05)$. Sonuç olarak; İnsan Kaynakları Yönetimi bölümü öğrencilerinin hastalığa karşı bilincinin artırılması ve aşılama karşıtı tutumlarının köreltilmesi için sağlık bilgisine olan ihtiyacı aşikardır. İnsan Kaynakları Yönetimi müfredatına sağlık bilgisi ve hastalık yönetimi ile ilgili dersler eklenebilir. Öğrenciler için bağışıklamaya yönelik eğitim, sempozyum ve paneller düzenlenebilir. Bunlar yardımıyla aşılamaya karşı asılsız bilgi kirliliği ortadan kaldırılmalı ve öğrenciler aşılamaya özendirilmelidir.
\end{abstract}

Anahtar Kelimeler: Alg1, Aş1, Covid-19, İnsan kaynakları yönetimi, Sağlık yönetimi.

\begin{abstract}
In this study, it was aimed to examine the perceptions and attitudes of university students towards the control and vaccine of Covid-19. In addition, the differences between the perceptions and attitudes of the students according to their departments, health education status and whether they have a Covid-19 case in their environment were examined. The population of the research consists of 730 students at a foundation university. The sample consists of 304 students based on the $95 \%$ confidence interval. Differences between variables were analyzed by independent sample t-test. As a finding of the research, the average of the students' attitudes towards the vaccine was $3.09 \pm 0,68$; control perception averages were determined as 2.820,53. According to the departments and health education status of the students, their perception of control towards the Covid-19 pandemic and the positive attitude subdimension towards the Covid-19 vaccine statistically differed significantly $(\mathrm{p}<0.05)$. However, it was determined that there was no statistically significant difference according to the negative attitude subdimension and the status of being a patient diagnosed with Covid-19 ( $p>0.05)$. As a result, It is obvious that the students of the Human Resources Management department need health information to increase their awareness of the disease and to blunt their antivaccination attitudes. Health information and disease management courses can be added to the Human Resources Management curriculum. Training, symposiums, and panels on immunization can be organized for students. With the help of these, unfounded information pollution against vaccination should be eliminated and students should be encouraged to vaccinate.
\end{abstract}

Keywords: Covid-19, Health management, Human resources management, Perception, Vaccine.

İstanbul Medipol Üniversitesi Girişimsel Olmayan Klinik Araştırmalar Etik Kurulu tarafindan E-10840098-772.02-979 sayı numarası ile 12/01/2021 tarihinde etik kurul izni alınmıştır.

1 Prof. Dr., Yeter DEMIR USLU, Yönetim ve Strateji, İstanbul Medipol Üniversitesi Sağllk Bilimleri Fakültesi Sağllk Yönetimi Bölümü, yuslu@medipol.edu.tr, ORCID: 0000-0002-8529-6466

2 Arş. Gör., Emre YILMAZ, Sağlık Yönetimi, İstanbul Medipol Üniversitesi Sağlık Bilimleri Fakültesi Sağlık Yönetimi Bölümü, emreyilmaz@medipol.edu.tr, ORCID: 0000-0003-4502-9846

3 Yüksek Lisans Öğrencisi, Umutcan ALTUN, Sağlık Yönetimi, İstanbul Medipol Üniversitesi Sağlık Bilimleri Fakültesi Sağlık Yönetimi Bölümü, umutcanaltun00@gmail.com, ORCID: 0000-0003-2452-1137 


\section{GİRIŞ}

Salgın hastalıklar, insanlığın tarih boyunca sıklıkla karşılaştı̆ğ, devletlere, toplumlara ve ekonomik faaliyetlere darbe vuran afetlerdendir. İnsan ırkını yüzyıllardır etkisi altına alan enfeksiyon hastalıkları, tüm insanlığa maddi ve manevi yükler getirmiş ve sosyal yaşamı felce uğratmıştır. ${ }^{1}$ İlk kez 2019'un sonunda Çin'in Wuhan kentinde ortaya çıkan, sonrasında da çok kısa bir sürede tüm dünyaya yayılan ve COVID-19 olarak adlandırılan yeni koronavirüs salgını da yaşantımızla birlikte dünya ekonomisini de derinden etkilemiştir. Salgının ilk günlerinde vakalar iki ya da üç haneli sayılarla ifade edilirken, yaklaşık 2 ay içerisinde dört ve beş haneli sayılar olarak raporlanmıştır. 30 Mart 2021 itibariyle dünya genelinde 548.050 yeni vaka ve 10.936 yeni ölüm bildirilirken; onaylanmış toplam vaka sayı1s1 128.815.631, toplam ölüm sayıs1 ise 2.815.257 olmuştur. Güncel verilere göre küresel anlamda vaka/ölüm oranı $\% 2,19$; Türkiye özelinde incelendiğinde 30 Mart 2021 tarihinde günlük 37.303 vaka sayısı ile toplam vaka sayıs1 3.277.880; günlük 155 ölüm sayısı ile toplam ölüm sayıs1 31.385 olarak raporlanmıştır. Türkiye'nin toplam vaka/ölüm oranı ise $\% 0,95{ }^{\prime}$ tir. $^{2}$

Küresel anlamda her konuda kriz ortamı oluşturan koranavirüs salgını için ülke liderleri ve sağl1k yöneticileri eş güdümlü çalışarak çeşitli tedbirler almış ve toplum sağlığını koruma yönünde politikalar geliştirerek uygulamaya koymuşlardır. Uluslararası Çalışma Örgütü'nün (International Labour Organization-ILO) söz konusu tedbirler için hazırladığı rapora göre 2020 16-22 Mart haftasinda 34 ülke tarafından 63 önlem açıklanmış ve uygulamaya başlanmıştır. Türkiye, Ocak ayından itibaren önlem hazırlıklarına başlamıştır. Sağlık Bakanlığı bünyesinde ilk olarak Covid-19 operasyon merkezi oluşturulmuş ve sonrasında "Koronavirüs Bilim Kurulu” kurulmuştur. 2020 Mart ay1 itibarı ile küresel anlamda uygulamaya konulan tedbirler genel olarak vergi reformu, sosyal harcama düzenlemeleri, sosyal program düzenlemeleri, yeni program veya yardım, yönetim ve sübvansiyon başlıklarıyla incelemeye alınmıştır. ${ }^{3}$

Mart ayından itibaren ülkeler tarafindan tedbir uygulamalarına ağırlık verilmiş ve çözüm önerileri üzerine yoğunlaşılmıştır. Ülkeler kara sınırlarını kapatmış, uçuşları durdurmuş ve kafeler ya da ibadet yerleri gibi sosyal mesafenin aşıldığı yerler süreli olarak kapatılmıştır. Caydırıcı olması için kurallara uymayan işletme veya kişilere para cezası uygulanmıştır. Çoğu ülke, belirli gün ve saatlerde sokağa çıkma yasağını getirmiştir. Pandeminin yıkıcı etkisinin tedbirler tarafından hafifletildiği görülse de önlemlerin yeterli olmadığ kazanması gerektiği günlük durum raporlarındaki vaka ve ölüm sayılarıyla anlaşılmıştır. Bunun üzerine pandemiden çıkış yolu olarak en etkili seçeneğin geçmişten günümüze birçok salgını engellemiş, toplum bağışıklığını artırmış ve bireylere sağlıklı bir gelecek sunmuş olan aşılar olduğu görülmüştür. Fakat ne yazık ki halk sağlı̆̆ biliminde en etkili sağlık hizmetlerinden olan aşı seçeneği, aşı reddi veya aşı karamsarlığ karşıya kalmaktadır. Bu karşı yaklaşımlar aşının ilk bulunduğu ve uygulandığ kadar dayanmaktadır. Çiçek hastalığı salgını sırasında çıkarılan zorunlu aşılama uygulamasıyla birlikte Londra'da Anti-Aşı Derneği kurulmuş ve aşıya karşı eylemler yapılmıştır. Geçmişte yaşanılan bu çatışmalar, günümüzdeki aşı karşıtlarının da öne sürdüğü vicdani ret kavramıla örtüşmektedir. ${ }^{4}$

Halk sağlığı biliminde temel koruyucu araçlarından biri olarak tanımlanan aşı; çeşitli enfeksiyon bulaşıcılığını engelleme ve oluşabilecek hastalıkların önüne geçme konusunda en etkili ve akılcı tıbbi yaklaşımlardandır. Aşı uygulamalarının temel hedefi; bireyleri hastalıklardan korumak, var olan hastalıkları kontrol altına almak ve hatta mümkünse eradike edebilmektir. ${ }^{5}$ Geçmişten günümüze aş1lar, salgın olarak nitelendirilen enfeksiyon hastalıklarının tedavisi için yapılan harcamaları düşürmüş ve salgınların kriz 
ortamı yaratmasını engellemeyi mümkün kılmıştır. Günümüzde de modern aş1 uygulamaları için çalışmalar yürütülmekte, var olan aşı uygulamalarının geliştirilmesi için çaba gösterilmektedir. ${ }^{6}$ Günümüze kadar yapılan aşı uygulamaları, çiçek hastalığı gibi dünyanın büyük bir kısmında görülen bazı salgın hastalıkları eradike etmeyi başarmış ve diğer benzeri salgın hastalıkların ise görülme insidansını azaltmıştır. Fakat tüm bu uygulama başarılarına rağmen Avrupa ve Amerika'da başlayan 'aşı reddi' yaklaşımı son 10 yıldır Türkiye'de de etkisini göstermeye başlamıştır. ${ }^{7}$

Literatür incelendiğinde aşı konusunun direkt olarak bireyleri ve yaşadıkları toplumu etkileyen bir konu olmasiyla güncelliğini koruyacağı kesindir. Hem aşının desteklenmesi hem de karşıt söylemler şu an gündemde olduğu gibi gelecekte de var olacaktır. $\mathrm{Bu}$ konu için değişkenlerin ve söylemlerin birlikte incelenmesi ve sonuca ulaştırılması, ardından bilimsel verilere dayalı kararlar verilmesi ve uygulanması planlanmalıdır. Toplum içinde kulaktan kulağa dolaşmış olan bilgi kirlilikleri yok edilmeli ve aslolan doğru bilgiye ulaşmaları için çalışmaların yürütülmesi gerekmektedir. Geçmişten günümüze kadar yapılmış olan çalışmalar incelendiğinde aşı uygulamalarının sağlığı korumak için güvenilir ve etkili bir hizmet sunumu olduğu görülmüştür. Çiçek hastalığı, difteri, boğmaca, kızamık, yeni doğan tetanosu, hepatit b, tüberküloz, çocuk felci gibi hastalıklarda engellenen ölüm oranı \%61 olarak hesaplanmıştır. Aşı tarihçesindeki uygulamalara bakıldığında da yine faydanın her zaman için daha fazla olduğu bilinmektedir. ${ }^{8}$ COVID-19 için geliştirilen aşının üretilmesi ve uygulanması da tüm dünya tarafından beklenen bir olaydır ve belki de bu salgından kurtulmanın en önemli yollarından biridir. Bu yüzden de aşılamanın önemi için tüm dünyada toplumları bilinçlendirme çalışmaları artırılmalı, aşıya karşı olan olumsuz yaklaşımları gidermek adına stratejik uygulama planlamaları yapılmalıdır. ${ }^{9} \quad$ Söz konusu olumsuz yaklaşımlar, aşıya karşı çoğu bireyde soğuk bir imaj yaratmıştır. Bu yaklaşımlara nazaran doğru olan ise, aşı uygulamalarının; bağışıklığ1 sağlamak adına halk sağlı̆̆1 çalışmaları arasında yer alan en önemli sağlık hizmetlerinden biri olmasıdır. Belirtilen tüm bu faktörler 1şı ğında toplumun, hem COVID19 pandemisi karşısındaki kontrol algısının hem de aşılama algısının ölçülmesi elzem bir konu olarak karşımıza çıkmaktadır.

\section{Geçmişten Günümüze Salgın Hastalıklar}

Toprağın işlenmesi, sürülmesi ve tarım çalışmaları ile hayvancılık faaliyetlerinin de artmasıyla insanoğlu daha önce hiç karşılaşmadığ 1 mikroplarla karşı karşıya kalmıştır. $\mathrm{Bu}$ mikropların insan vücuduna geçişi ve zamanın tıp biliminin yetersiz olmasıyla ilk salgınlar oluşmaya başlamıştır. Salgınların temel nedenleri genel olarak yaşam stillerindeki değişim, nüfus artışları, seyahat ve ticaretin artmasi olarak bilinmektedir. ${ }^{10}$ İnsanlar ilk çağlarda salgınların nedenini tam olarak bulamadığ için bu enfeksiyon yayılımlarına karşı çaresiz kalmışlardır. ${ }^{11}$ 165-180 y1llarına kadar dayanan ve 'Antonin Veba' olarak adlandırılan ilk salgından, günümüzde savaşını verdiğimiz Covid-19 pandemisine kadar ortalama 20 büyük salgın yaşanmış ve hemen hemen 400 milyon birey yaşamını yitirmiştir. $^{12}$ Geçmişe baktığımızda 14. yüzyıl için veba, 15 . ve 17 . yüzyıllar arası için çiçek salgını ve 20. yüzyıl için İspanyol Gribi büyük yıkım ve kriz olarak karşımıza çıkarken, içinde bulunduğumuz dönemin yıkıcı ve ilk evrensel krizi de Covid-19 pandemisidir. ${ }^{13}$ Aşağıda geçmişten günümüze yüksek ölüm sayıları ile sonuçlanan salgın hastalıklar listelenmiştir. ${ }^{12}$

- 165-180 yıllar1 Antonin Veba; 5 milyon ölüm,

- 541-542 yılları Jüstinyen Vebası; 3050 milyon ölüm,

- 757-737 yı1ları Japon Çiçek Hastalığ1 salgını; 1 milyon ölüm,

- 1347- 1351 yılları Kara Veba; 200 milyon ölüm,

- 1520 - sonrası Çiçek Hastalığı salgını; 56 milyon ölüm, 
- 1918-1919 yılları İspanyol Gribi; 4050 milyon ölüm,

- 1981-günümüz HIV-AIDS; 25-35 milyon ölüm gerçekleşmiştir.

\section{Bağışıklama Çalışmalarının Mucizevi Çıktısı: 'Aşıı'}

Geçmişten günümüze tüm yaşamı etkisi altına alan ve insan yaşamını sekteye uğratan salgınlar için çeşitli korunma ve başa çıkma çabaları verilmiştir. Yapılan tüm bu çalışmaların sonunda 'modern tıbbın mucizesi' olarak adlandırılan 'aşı' bulunmuştur., ${ }^{4,14}$ İnsan ve hayvanlarda hastalık yapma yeteneğinde olan virüs, bakteri vb. mikropların hastalık yapma özelliklerinden arındırılarak ya da bazı mikropların salgıladığı toksinlerin etkileri ortadan kaldırılarak geliştirilen biyolojik ürünlere aşı denilmektedir. ${ }^{15}$ Aşıların geliştirilmesinin başlangıç noktası olarak; 15 . ve 17. yüzyılları arasında büyük bir yıkım getiren ve 56 milyon kişinin ölümüne neden olan çiçek salgınının eradike edilmesi çalışmaları bilinmektedir. $\mathrm{Bu}$ anlamda Edward Jenner literatürde aşılama üzerindeki yenilikçi çalışmalarıyla bilinmekte ve çiçek hastalığının eradike edilmesi konusunda öncü kişi olarak anılmaktadır. ${ }^{16,17}$ Jenner'ın ilk başarılı bağışıklama uygulaması sonrasında 19. yüzyıl sonlarına gelindiğinde modern aşı uygulama çalışmalarıyla birlikte önemli gelişmeler yaşanmıştır. Tüm bu çalışmalar 1şığında hücre kültürü ve moleküler biyoloji çalışmalarına ağırlık verilmiş, yeni aşı buluşları için önemli adımlar atılmıștır. ${ }^{18}$ Aşağıda tarih boyunca bulunan ve geliştirilen bazı aşıların isimleri, uygulanma tarihleri ve geliştiren/bulan kişiler kronolojik sırayla verilmiştir.

- 1796 yılı Çiçek aşısı Jenner tarafindan,

- 1885 yılı Kuduz aşısı Pasteur tarafindan,

- 1892 yılı Kolera aşısı Haffkine tarafindan,

- 1897 y1lı Lepra aşısı Wright tarafindan,
- 1897 yılı Veba aşısı Haffkine tarafindan,

- 1903 yılı Veba (Canlı) aşısı Strong tarafindan,

- 1913 yılı Difteri aşısı Behring tarafindan,

- 1915 yılı Tifüs aşısı Reşat Rıza ve Tevfik Salim tarafından,

- 1923-1926 y1lı Boğmaca aşısı Madsen tarafindan,

- 1949 y1lı Kabakulak (Canlı) aşısı Smorodintsev tarafindan,

- 1960-1964 y1lı Kızamık aşı1 Edmonston / Schwarz tarafindan,

- 1962-1970 yılı Kızamıkçık aşısı Weller / Neva / Parkman tarafindan,

- 1976-1981 y1lı Hepatit B aşısı Maupas / Hillemann tarafindan,

- 1979 yılı Hepatit A aşısı Provost / Hillemann tarafından,

- 2020 yılı Covid-19 aşısı Uğur Şahin/Özlem Türeci tarafindan bulunmuştur.

Jenner'ın 1789 yılında çiçek hastalığının eradike edilmesi için yaptığı çalışmalar, bağışıklama üzerine yapılan modern çalışmaların başlangıcıdır. ${ }^{20}$ Aşı uygulamaları ile salgınların önüne geçilmesi hedeflenmiştir. Yapılan çalışmalarla birçok salgın hastalığın önüne geçilmesi sağlanmış ve tedavi için harcanacak maliyetler azaltılmıştır. ${ }^{6}$ Aşılama, günümüzün en etkili ve başarılı, aynı zamanda maliyet etkin girişimlerindendir. Dünya Sağlik Örgütü (DSÖ) verilerine göre her yıl difteri, tetanoz, boğmaca, grip ve kızamık gibi enfeksiyon hastalıklardan dolayı yaşanabilecek ortalama 2-3 milyon ölümün önüne geçildiği bilinmektedir. $^{21}$

Türkiye'de Bağışıklama ile Elde Edilen Başarılar

Bağışıklama çalışmaları sonucunda hastalık seyrinde önemli düşüşler meydana gelmiştir. Özellikle 1924-1944 yılları arasında büyük bir yıkıma sebep olan çiçek 
hastalığı salgınının eradike edilmesi çalışmaları sonuç vermiş ve 1977 yılından itibaren hastalık tamamen yok edilmiştir. Bunun üzerine tüm dünyada ve Türkiye'de 1980 yılından itibaren çiçek aşısı uygulamaları durdurulmuştur. Yine bir diğer örnek olarak çocuk felci (poliomiyelit) hastalığı için dünyada yaygın aşı uygulamaları yapılmış ve hastalık neredeyse yok edilmiştir. 1988 'de dünya üzerinde 350.000 toplam vaka sayısına ulaşan hastalık, 2017 yılında 22 vakaya kadar düşmüştür. $\mathrm{Bu}$ hastalık ile ilgili Türkiye'de en son Kasım 1998 yılında vaka görülmüştür. Kızamık vaka sayıları için 2001 yılına baktığımızda 30.509 vaka bildirilirken, aşı uygulamaları sonucunda bu sayı 2017 yılında 84 ile sinırlı kalmıştır. Yine Türkiye için maternal ve neotonal tetanoz vakaları incelendiğinde DSÖ tarafindan 24 Nisan 2009 tarihinde hastalığın elimine edildiği belgelenmiştir. 2004 yılından itibaren yalnızca 2011 yılında 1 difteri ve ölüm vakası olup, bu vaka dışında vaka bildirilmemiştir. 2017 yılında Türkiye'de 25 tetanoz vakası görülmüştür. 2'si ölüm ile sonuçlanan vakaların tamamının aşısız olduğu bilinmektedir. ${ }^{22}$

1932- 1936 yılları arasında 1236 Difteri vakası görülüyor iken aşılama çalışmalarıyla birlikte bu say1 neredeyse \%100 azalarak 2014 yılında 0,2 vakaya düşmüştür.

1958- 1962 yılları arasında görülen 501 çocuk felci vakası var iken aşılamayla birlikte bu sayı 2014 yılında \%100 eradike edilerek 0'a düşürülmüştür.

1963-1967 yılları arasinda 10761 Boğmaca vakası tespit edilmişken etkin bağışıklama ile bu oran 2014 yılında \%99,5 azalış göstererek 49 vakaya düşürülmüştür.

1965-1969 yılları arasında 50144 Kızamık vakası görülüyor iken 2014 yılında bu sayı $\% 96,6$ oranında azaltılarak 1689'a düşürülmüştür.

\section{Dünyada ve Türkiye'de Aşıya Karşı Olumsuz Yaklaşımlar: Aşı Kararsızlığı ve Aşı Reddi}

Dünya üzerinde özellikle son 20 yılda ivme kazanan aşı karşıtı yaklaşımlar için Dünya Sağlık Örgütü 2012 yılında 'Aş1
Tereddütü Çalışma Grubu'nu (Vaccine Hesitency Working Group) oluşturmuştur. Komisyon raporuna göre aşı kararsızlığ 1 (aş1 tereddütü) ve aşı reddi kavramları farklı tanımlarla literatürde yer almıştır. ${ }^{23}$ Aş1 uygulamalarına karşı kararsızlık yaklaşımı, aşılama hizmetlerinin mevcut olmasına rağmen kabulünün geciktirilmesi veya süreç sonunda reddetme anlamına gelirken; aşı reddi yaklaşımı direkt olarak aşıyı kabul etmeme anlamina gelmektedir. ${ }^{24}$ Yani dünyada aşı karşıtı yaklaşımlar içerisinde bazıları aşıyı direkt reddederken; bazıları aşı olmayı geciktirmekte ya da aşıyı kabul edip direkt olarak aşı olmakta emin değildirler. Aşı kararsızlığ1 (tereddütü) yaklaşımında bulunan bireyler, tüm aşıları kabul edenler ve aşı reddinde bulunanlar arasındaki heterojen gruplardır. Bunların yanı sira yapılan araştırmalara göre, aşı yaptıran kişilerin bile aşılama uygulamaları için şüphe ve kaygıları olabileceği bilinmektedir. ${ }^{25}$

Dünya tarihine bakıldığında aşı karşıtı yaklaşımların başlangıç noktasının, Edward Jenner'ın çiçek salgını için yaptığ sonucunda 'aşı' kavramını bilim dünyasına kazandırdığ 1 döneme dayandığ bilinmektedir. ${ }^{4,8}$ Jenner'ın çalışmaları sonucunda İngiltere'de yaygın aşılama uygulamasına başlanmış, bu uygulamaya takriben de 1840-1853 y1lları arasında aşılama İngiltere'de zorunlu hale gelmiştir. Söz konusu zorunlu uygulama politikasına karşın aynı yıl içerisinde Londra'da Anti-Aş1 Derneği (Anti-Vaccination League) kurulmuştur. Dernek eylemleri sürerken devam eden yıllarda 1867 yasasıyla aşı zorunluluğu 14 yaşa kadar genişletilmiştir. $\mathrm{Bu}$ yasa, aşı karşıtlarını daha da tetiklemiş ve kitaplar, broşürler, dergilerle aşı karşıtı eylemler gerçekleştirilmiştir. Söz konusu bu eylemler bağışıklama oranlarında ciddi düşüşlere sebebiyet vermiş, fakat 2 yıl sonra ortaya çıkan büyük bir salgın sonucu yaygın aşılamaya yeniden dönülebilmiştir. ${ }^{4}$

Türkiye özelinde incelendiğinde yaklaşık son 10 yıldır aşı reddi hareketinin başladığı ve artış gösterdiği bilinmektedir. Önceleri çok az düzeyde olan aşı karşıtı yaklaşımlar, 2015 yılındaki aşı uygulaması için 
ebeveynden onam alınması konusuyla alakalı kazanılan bir dava ve aşı karşıtı söylemlerin medyada yer alması sonucunda artışa uğramıştır. Çocuklarını aşılatmak istemeyen ailelerin sayıs1 2011 y1lında 183'ken, 2013 y1lında 980, 2015 y1lında 5400, 2016 y1lında 12000 ve 2018 yılında iste yaklaşık 23000'e ulaşmıştır. ${ }^{26}$ Ayrıca aşı karşıtı yaklaşımların bir çıktısı olarak 2018 yılında kızamık vakasının artış gösterdiği ve 2019 yılında hastalığın pik (zirve) yaptığı da bilinmektedir. $^{27}$

Aşıya karşı olan olumsuz yaklaşımlar sonucunda aşılama oranlarının düştüğü ve bağışıklama çalışmalarıyla önlenebilir bulaşıcı hastalıkların görülmesinde artış yaşandığı bilinmektedir. Bireylerin aşılara karşı olumsuz yaklaşımlarının altında birçok neden vardır. Aşı karşıtlığı düşüncesi; içinde bulunulan zamana, bölgeye ve aşıya göre değișen karmaşık, bağlama özgü küresel bir sorun ve sağlık tehtididir. ${ }^{28,29}$

Dünya Sağlık Örgütü'ne göre aşılamayı engelleyen faktörler aşağıdaki gibi gruplandırılmıştır; ${ }^{30}$

Birey ve Grup Etkileri; Geçmiş aş1 uygulamaları tecrübeleri, sağlık ve önleyici uygulamaya ilişkin inanç ve yaklaşımlar, bilgi/farkındalık, sağlık sistemi ve sağlayıcılara güven, kişisel deneyimler, risk/yarar, sosyal normlardır.

Bağlamsal Etkiler; İletişim ve medya araçları, toplum üzerinde etkili kişiler ve aşı karşıtı/ destekleyicisi lobiler, tarihi etkiler, sosyo-demografik özellikler, politikalar/yasalar, coğrafi engeller, ilaç endüstrisidir.

Aşı ve Aşılamaya Ait Etkiler; Riskler/yararları (bilimsel kanıtlara dayalı), aşı programlarının düzenlenmesi, ulaştırma şekli, uygulama şekli, yeni aşı veya yeni formülasyonların tanıtımı, aşı kaynaklarına ulaşım, aşılama takvimi, maliyet, sağlık çalışanlarının rolü olmak üzeredir.

\section{Problemin Tanımı}

Hayatımızı her yönü ile çevrelemiş ve toplumsal yaşamımızı tehdit eden COVID-19 virüsünün aşı çalışmalarına karşı bilgi kirliliğinden doğan 'aşı karşıtlığı' ve 'karamsarlık' yaklaşımları gündemi meşgul etmektedir. Aşı karşıtlığı ya da karamsarlığı, ülkemizde ve dünyada artmakta olan ve enfeksiyon hastalıklarının eradike edilmesi ya da bu hastalıklardan korunulması konusunda ciddi olumsuz sonuçlar doğurabilecek yaklaşımlardır.

$\mathrm{Bu}$ çalışmada da üniversite öğrencilerinin Covid-19'un kontrolüne ve aşısına yönelik alg1 ve tutumlarının incelenmesi amaçlanmıştır. Ayrıca öğrencilerin bölümlerine, sağlık eğitimi alma durumlarına ve çevresinde Covid-19 vakası olma durumlarına göre de aşıya yönelik kontrol, alg1 ve tutumları arasındaki farklılıklar incelenmiştir.

\section{MATERYAL VE METOT}

\section{Araştırmanın Tipi, Yeri ve Zamanı}

$\mathrm{Bu}$ araştırma kesitsel ve tanımlayıcı nitelikte bir çalışmadır. İstanbul'daki bir vakıf üniversitesinin 2020-2021 eğitim öğretim yılında öğrenimine devam eden Sağlık Yönetimi ve İnsan Kaynakları Yönetimi bölümü öğrencilerine uygulanmıştır.

\section{Araştırmanın Evreni ve Örneklemi}

Araştırmanın evreni, çalışmanın yapıldı̆̆ 1 tarihlerde İstanbul'daki bir vakif üniversitesinde eğitim gören 420 Sağlık
Yönetimi ve 310 İnsan Kaynakları Yönetimi Bölümü öğrencilerinden olmak üzere toplam 730 öğrenciden oluşmaktadır. Araştırmanın örneklemi belirlenirken kolayda örnekleme yöntemi kullanılmıştır Örneklemin büyüklüğü belirlenirken ise Raosoft web tabanından yararlanılmıştır. Örneklem büyüklüğü \%95 güven aralığı esas alınarak en az 252 öğrenci olarak hesaplanmış 316 kişiye ulaşılmış, gürültülü verilerin ve eksik alanların olduğu anketler analizden çıkarılarak 304 anket çalışmaya dahil edilmiştir. 


\section{Veri Toplama Araçları}

Araştırmanın verileri anket yardımı ile toplanmıştır. Anket, sosyo-demografik bilgiler, COVID-19 Kontrol Algısı Ölçeği (Perception of Control of COVID-19 [PCoCOVID-19]) ve COVID-19 Aşısına Yönelik Tutumlar Ölçeği (Attitudes Towards the COVID-19 Vaccine [ATV-COVID-19]) olmak üzere 3 bölümden oluşmaktadır. ${ }^{33}$ Anketin birinci bölümünde 7 sorudan oluşan sosyo-demografik özellikleri belirten sorular, ikinci bölümünde ise 12 soruluk PCoCOVID-19 ölçeği, üçüncü bölümünde ise 9 soruluk ATV-COVID-19 ölçeği yer almaktadır.

\section{COVID-19 Kontrol Algısı Ölçeği (Perception of Control of COVID-19 [PCo-COVID-19])}

COVID-19'un Kontrolü Algis1 Ölçeği, on iki maddeden oluşmaktadır. Ölçek beşli likert yapıdadır. Bulunan ifadeler "Kesinlikle katılmiyorum (1)", "Katılmiyorum (2)", "Kararsızım (3)", "Kat1liyorum (4)", "Kesinlikle katıliyorum (5)" şeklinde değerlendirilmektedir. Makro kontrol, kişisel (mikro) kontrol ve kontrol edilebilirlik olmak üzere üç alt boyuttan oluşmaktadır.

Makro kontrol; kurumsal, ulusal ya da küresel düzeyde alınan tedbirlerin etkililiğine ilişkin inançlarla ilgilidir. Kişisel kontrol olarak isimlendirilen ikinci alt boyut hastalığa yakalanmamak için alınan kişisel tedbirlerin etkililiği ile ilgilidir. Son alt boyut ise hastalığın kontrol edilebilirliği ile ilgili algıyı değerlendiren boyutudur.

- Makro Kontrol Boyutu; [1-4] sorular,

- Kişisel (Mikro) Kontrol Boyutu; [5-8] sorular,

- Kontrol Edilebilirlik Boyutu; [9-12] sorular.

Kontrol edilebilirlik alt boyutundaki maddeler ters olarak puanlanmaktadır. Ölçek alt boyutundaki madde puanlarının toplanmasiyla elde edilen toplam puanın o alt boyuttaki madde sayısına bölünmesiyle 1-5 arasında bir değer elde edilir.
Makro kontrol alt boyutundaki yüksek puanlar alınan önlemlerin yeterli olduğunu, kişisel kontrol boyutundaki yüksek puanlar kişisel tedbirlerle hastalığın kontrolün iyi düzeyde sağlanabileceğini ve kontrol edilebilirlik alt boyutundaki yüksek puanlar ise hastalığın kontrol edilebileceği inancını yansıtmaktadır. Ölçeğin Cronbach Alpha değeri 0,79 olarak bulunmuştur. ${ }^{31}$

COVID-19 Aşısına Yönelik Tutumlar Ölçeği (Attitudes Towards the COVID-19 Vaccine [ATV-COVID-19])

COVID-19 Aşısına Yönelik Tutumlar Ölçeği, 9 maddeli olup, iki alt boyuta (olumlu ve olumsuz tutum) sahiptir. Ölçekte bulunan ifadeler "Kesinlikle katılmıyorum (1)", "Katılmıyorum (2)", "Kararsızım (3)", "Kat1liyorum (4)", "Kesinlikle kat1lyorum (5)" şeklinde değerlendirilmektedir.

Olumsuz tutum alt boyutlarındaki maddeler ters olarak puanlanmaktadır. Ölçek alt boyutundaki madde puanlarının toplanmasiyla elde edilen toplam puanın o alt boyuttaki madde sayısına bölünmesiyle 1-5 arasında bir değer elde edilir.

Olumlu tutum alt boyutundan alınan yüksek puanlar, aşıya yönelik tutumun olumlu olduğunu göstermektedir. Olumsuz tutum alt boyutundaki maddeler ters çevrildikten sonra hesaplanır ve bu alt boyut puanlarındaki yükseklik, aşıya karşı olumsuz tutumun daha az olduğunu göstermektedir. Ölçeğin Cronbach Alpha değeri 0,80 olarak bulunmuştur. ${ }^{31}$

- Olumlu Tutum Boyutu; [1-4] sorular,

- Olumsuz Tutum Boyutu; [5-9] sorular.

\section{Araştırmanın Değişkenleri}

COVID-19 Kontrol Algısı Ölçeği ve COVID-19 Aşısına Yönelik Tutumlar Ölçeği'nden elde edilen puanlar araştırmanın bağımlı değişkenlerini oluşturmaktadır. Yaş, cinsiyet, bölüm, sınıf, sağlıkla ilgili ders alma durumu, Covid-19 teşhisi konulan hasta durumu değişkenleri ise araştırmanın bağımsız değişkenlerini oluşturmaktadır. 


\section{Araştırmanın Analizi}

Araştırmanın analizleri IBM SPSS 25.0 (Versiyon) istatistik paket programı ile yapılmıştır. İlk aşamada ortalama, standart sapma, yüzdelikler, frekans dağılımları gibi tanımlayıc1 istatistiksel analizlere yer verilmiştir. Sonraki aşamada değişkenlerin normal dağılıma uygunluğu test edilmiştir. Sayısal değişkenlerin normal dağılıma uygun olup olmadığını incelemek için; Kolmogorov-Smirnov değerine, SkewnessKurtosis değer aralığına, Histogram/Stemand-Leaf-Plot/Q grafiklerine ve Observed Value sonuçlarına bakılmıştır. İki değişkenin karşılaştırılması Independent Samples T test ile yapılmıştır.

\section{Araştırmanın Kısıtlılıkları}

Çalışma, COVID-19 pandemi sürecinde üniversitelerin uzaktan eğitime geçmesi sebebiyle veri toplama araci online platformda bir üniversitenin iki bölümünde 303 kişi ile yapılmıştır.

\section{Araştırma Etiği}

Araştırmanın bilimsel açıdan uygun olduğu, İstanbul Medipol Üniversitesi Girişimsel Olmayan Klinik Araştırmalar Etik Kurulu tarafindan 12/01/2021 tarih, E10840098-772.02-979 say1l karar ile onaylanmıştır. Covid-19 ile ilgili bir araştırma olduğu için Sağlık Bakanlığı Sağlık Araştırmaları Genel Müdürlüğü, COVID-19 Bilimsel Araştırma Değerlendirme Komisyonu tarafından 06/01/2021 tarihinde çalışmaya uygunluk verilmiştir.

\section{BULGULAR VE TARTIŞMA}

Araştırmanın konusuna ilişkin anket sorularına, öğrencilerin ölçeğe verdikleri cevaplar güvenilirlik analizi ile test edilmiştir. COVID-19 Kontrol Algısı Ölçeği'nin Cronbach's Alpha değeri; 0,73; COVID-19 Aşısına Yönelik Tutumlar Ölçeği'nin ise 0,84 olarak bulunmuştur. Her iki ölçeğin de güvenilirliği yüksektir. Araştırmaya katılan öğrencilerin sosyodemografik verilerine göre dağılımı Tablo 1 'de yer almaktadır.

Tablo 1. Öğrencilerin Sosyo-demografik Özellikleri

\begin{tabular}{lrr}
\hline Değişkenler & Frekans (n) & Yüzde (\%) \\
\hline Yaş & & \\
$17-20$ & 120 & 39,6 \\
$21-24$ & 171 & 56,4 \\
$25+$ & 12 & 4,0 \\
\hline Cinsiyet & & \\
Kadın & 246 & 81,2 \\
Erkek & 57 & 18,8 \\
\hline Bölüm & & \\
Sağlik Yönetimi & 169 & 55,8 \\
İnsan & 134 & 44,2 \\
Kaynakları & & \\
Yönetimi & & \\
\hline Sinıf & & \\
1.Sinıf & 86 & 28,4 \\
2.Sinıf & 50 & 16,5 \\
3.Sınıf & 48 & 15,8 \\
4.Sınıf & 119 & 39,3 \\
\hline
\end{tabular}

Tablo 1 (Devamı). Öğrencilerin Sosyo-demografik Özellikleri

\begin{tabular}{lrr}
\hline Sağlık Eğitimi Alma & & \\
Evet & 131 & 43,2 \\
Hayır & 172 & 56,8 \\
\hline Çevredeki Covid-19 Hastası & & \\
Var & 236 & 77,9 \\
Yok & 67 & 22,1 \\
Toplam & $\mathbf{3 0 3}$ & $\mathbf{1 0 0}$ \\
\hline
\end{tabular}

Tablo 1'de tanımlayıcı verileri yer alan 303 kişinin yaş gruplarına göre dağılımları incelendiğinde 56,4'ünün 21-24 yaş aralığında olduğu, 39,6'sının 17-20 yaş aralığında olduğu, \%4'ünün ise 25 ve üzeri yaşındaki kişilerden oluştuğu görülmektedir.

Öğrencilerin \%81,2'si kadın, \%18,8'i ise erkektir. Ankete katılanların \%55,8'i Sağlık Yönetimi Bölümü, \%44,2'si ise İnsan Kaynakları Yönetimi Bölümü öğrencisi olduğu bilinmektedir. Öğrencilerin sınıflarına bakıldığında ise \%39,3'ünün 4.sinıf, $\% 28,4$ 'ünün 1.sinıf $\% 16,5$ 'inin 2.sinif ve $\% 15,8$ 'inin ise 3. Sınıf olduğu görülmektedir.

Ankete katılan öğrencilerin sağlıkla ilgili bir ders alma durumlarına bakıldığında $\% 56,8$ 'inin sağlıkla ilgili ders almadığ $\% 43,2$ 'sinin ise en az bir ders aldığı tespit edilmiştir. 
Öğrencilerin \%77,9'unun çevresinde Covid-19'a yakalanan hasta kişiler bulunurken \%22,1'inin ise çevresinde hiç Covid-19 tanısı konulan bireye rastlanmadığı tespit edilmiştir.
Tablo 2'de öğrencilerin COVID-19 aşısına yönelik tutum ve kontrol algısının bölümlere göre anlamlı olarak farklılaşıp farklılaşmadığı grupların puan ortalamaları üzerinden test edilmiştir.

Tablo 2. Öğrencilerin Covid-19 Aşısına Yönelik Tutumlarının ve Kontrol Algısının Bölümlerine Göre Farklılığını İnceleyen T Testi

\begin{tabular}{|c|c|c|c|c|}
\hline Bölüm & $\mathbf{n}$ & $\begin{array}{l}\text { Aşıya Yönelik Tutum } \\
(\mathrm{X} \pm \text { Sd })\end{array}$ & $\mathbf{t}$ & $\mathbf{p}$ \\
\hline Sağlık Yönetimi & 169 & $3,19 \pm 0,69$ & 2,71 & $0,007 *$ \\
\hline İnsan Kaynakları Yönetimi & 134 & $2,98 \pm 0,65$ & & \\
\hline Toplam & 303 & $3,09 \pm 0,68$ & & \\
\hline Bölüm & $\mathbf{n}$ & $\begin{array}{l}\text { Kontrol Algısı } \\
(\mathrm{X} \pm \text { Sd })\end{array}$ & $\mathbf{t}$ & $\mathbf{p}$ \\
\hline Sağlık Yönetimi & 169 & $2,93 \pm 0,49$ & 4,17 & $\mathrm{p}<0,001 * *$ \\
\hline İnsan Kaynakları Yönetimi & 134 & $2,68 \pm 0,54$ & & \\
\hline Toplam & 303 & $2,82 \pm 0,53$ & & \\
\hline
\end{tabular}

Tablo 2 incelendiğinde öğrencilerin aşıya yönelik tutum ortalamaları $3,09 \pm 0,68$ orta düzeyde; kontrol algısı ortalamaları ise $2,82 \pm 0,53$ orta düzeyde bulunulmuştur. Analiz sonucunda aşıya yönelik tutum ve kontrol algıları bölümlerine göre farklılık gösterdiği görülmektedir. Sağlık Yönetimi $(3,19 \pm 0,69)$ ve İnsan Kaynakları Yönetimi $(2,98 \pm 0,65)$ bölümü öğrencilerinin Covid-19 aşısına yönelik tutum ortalamaları birbirinden farklıdir $(\mathrm{t}=2,71, \quad \mathrm{p}<0,05)$. $(\mathrm{p}<0,05)$. Sağlık Yönetimi Bölümü öğrencilerinin Covid-19 aşısına yönelik tutumları istatistiksel olarak İnsan Kaynakları Yönetimi Bölümü öğrencilerden daha yüksek olduğu bulunmuştur. $\mathrm{Bu}$ durum Sağlık Yönetimi öğrencilerinin Covid-19 aşısı hakkındaki farkındalık düzeylerinin daha fazla olduğu ile açıklanabilir. Alan yazında bu kanıyı destekler nitelikte Sağlık Yönetimi öğrencileri konusundaki çalışmalar da mevcuttur. $^{32}$

Tablo 2'ye göre öğrencilerin Covid-19 kontrol algısı analiz sonucunda bölümlerine göre farklılık gösterdiği görülmektedir. $\mathrm{Bu}$ analize göre Sağlik Yönetimi $(2,93 \pm 0,49)$ ve İnsan Kaynakları Yönetimi $(2,68 \pm 0,54)$ bölümü öğrencilerinin Covid-19 kontrol alg1lar1 ortalamaları birbirinden farklılık göstermektedir. Sağlık Yönetimi Bölümü öğrencilerinin Covid-19 hastalığına yönelik kontrol algıları istatistiksel olarak İnsan Kaynakları Yönetimi Bölümü öğrencilerinden daha yüksek olduğu saptanmıştır $(\mathrm{t}=4,17, \mathrm{p}<0,05) . \quad \mathrm{Bu}$ durum Sağlık Yönetimi öğrencilerinin Covid-19'a karşı ülke genelinde uygulanan önlemlere ve politikalara, kişisel olarak alınan tedbirlere ve hastalığın kontrol altına alınmasına olan inançlarının daha fazla olduğunu göstermektedir. Sağlık alanında alınan eğitimler ve salgın hastalıklara olan bakış açısının farklı olması bu durumu açıklar niteliktedir. Yapılan bir başka çalışmada da kişilerin koronavirüs salgını karşısındaki kontrol algılarının eğitim değişkenine göre farklılık gösterdiği ve sağlık bilgisi eksikliğinden dolayı ortaya çıkan sağlık anksiyetesi düzeylerinin de etkinlendiği tespit edilmiştir. ${ }^{33}$

Tablo 3'te öğrencilerin COVID-19 aşısına yönelik tutum ve kontrol algısının sağlık eğitimi almalarına göre anlamlı olarak farklılaşıp farklılaşmadığı grupların puan ortalamaları üzerinden test edilmiştir. 
Tablo 3. Öğrencilerin Covid-19 Aşısına Yönelik Tutumlarının ve Kontrol Algısının Sağlık Eğitimi Almalarına Göre Farklılığını İnceleyen T Testi

\begin{tabular}{|c|c|c|c|c|}
\hline $\begin{array}{l}\text { Sağlık Eğitimi Alma } \\
\text { Durumu }\end{array}$ & $\mathbf{n}$ & $\begin{array}{l}\text { Aşıya Yönelik Tutum } \\
(\mathrm{X} \pm \text { Sd })\end{array}$ & $\mathbf{t}$ & $\mathbf{p}$ \\
\hline Evet & 131 & $3,22 \pm 0,67$ & 2,94 & $0,004 *$ \\
\hline Hayır & 172 & $2,99 \pm 0,67$ & & \\
\hline Sağlık Eğitimi Alma & $\mathbf{n}$ & $\begin{array}{l}\text { Kontrol Algısı } \\
(\mathrm{X} \pm \mathrm{Sd})\end{array}$ & $\mathbf{t}$ & $\mathbf{p}$ \\
\hline $\begin{array}{l}\text { Evet } \\
\text { Hayır }\end{array}$ & $\begin{array}{l}131 \\
173\end{array}$ & $\begin{array}{l}2,91 \pm 0,53 \\
2,75 \pm 0,51\end{array}$ & 2,60 & $0,010^{*}$ \\
\hline
\end{tabular}

$* p<0.05$

Tablo 3 incelendiğinde öğrencilerin Covid-19 aşısına yönelik tutumları analiz sonucunda sağlık eğitimi almalarına göre farklılık gösterdiği görülmektedir. Bu analize göre sağlık eğitimi alan öğrencilerin $(3,22 \pm 0,67)$ ve sağllk eğitimi almayan öğrencilerin $(2,99 \pm 0,67)$ Covid-19 aşısına yönelik tutum ortalamaları birbirinden farklıdır $(\mathrm{t}=2,94, \mathrm{p}<0,05)$. Sağlık eğitimi alan öğrencilerin Covid-19 aşısına yönelik tutumları sağlık eğitimi almayan öğrencilere oranla daha yüksek olduğu tespit edilmiştir.

Tablo 3'e göre öğrencilerin Covid-19 kontrol algısı analiz sonucunda sağlık eğitimi almalarına göre farklılık gösterdiği görülmektedir. Analize göre sağl1k eğitimi alan öğrencilerin $(2,91 \pm 0,53)$ ve sağlik eğitimi almayan öğrencilerin $(2,75 \pm 0,51)$ Covid-19 kontrolü algı düzeyleri ortalamaları birbirinden farklıdır $(\mathrm{t}=2,60, \mathrm{p}<0,05)$. Sağlık eğitimi alan öğrencilerin Covid-19 kontrolü algılarının sağlık eğitimi almayan öğrencilerden istatistiksel olarak daha yüksek olduğu tespit edilmiştir.
$\mathrm{Bu}$ durum koronavirüs hastalığg kontrol algısının oluşması ve aşıya yönelik olumlu tutumun gelişmesi için sağlık eğitiminin önemini ifade edebilir. Alan yazında yapılan bir başka çalışma da ise sağlık okuryazarlığı düşük olan birey ve toplumlarda bilgi eksikliği ve kişisel hijyenin düşük olması sebebiyle bulaşıcı hastalıklardan ve salgınlardan daha çok etkilenildiği, tedaviye uyum sağlamanın aksatıldığı ve bunun sonucunda morbidite ve mortalite oranlarının artarak sağlık sistemlerine ağır yükler getirdiği ifade edilmiştir. ${ }^{34}$ Bir başka çalışmada ise yetişkin bireylerin bağışıklama politikalarına uyum sağlaması amacıyla hastalıklar ve aşılar hakkındaki güncel sağlık bilgilerinin aktarılarak bilinç seviyelerinin artırılması gerekliliği tespit edilmiştir. ${ }^{35}$

Tablo 4'te öğrencilerin COVID-19 aşısına yönelik tutum ve kontrol algısının çevresinde Covid-19 hastası olmalarına göre anlamlı olarak farklılaşıp farklılaşmadığı grupların puan ortalamaları üzerinden test edilmiştir.

Tablo 4. Öğrencilerin Covid-19 Aşısına Yönelik Tutumlarının ve Kontrol Algısının Çevresinde Covid-19 Hastası Olmasına Göre Farklılığını İnceleyen T Testi

\begin{tabular}{|c|c|c|c|c|}
\hline $\begin{array}{l}\text { Çevresinde Covid-19 } \\
\text { Hastası Olma Durumu }\end{array}$ & $\mathbf{n}$ & $\begin{array}{l}\text { Aşıya Yönelik Tutum } \\
\mathrm{X} \pm \text { Sd }\end{array}$ & $\mathbf{t}$ & $\mathbf{p}$ \\
\hline Var & 236 & $3,13 \pm 0,69$ & 1,90 & 0,057 \\
\hline Yok & 67 & $2,95 \pm 0,62$ & & \\
\hline $\begin{array}{l}\text { Çevresinde Covid-19 } \\
\text { Hastası Olma Durumu }\end{array}$ & $\mathbf{n}$ & Kontrol Algısı $\mathrm{X} \pm$ Sd & $\mathbf{t}$ & $\mathbf{p}$ \\
\hline Var & 236 & $2,82 \pm 0,55$ & 0,02 & 0,984 \\
\hline Yok & 67 & $2,82 \pm 0,41$ & & \\
\hline
\end{tabular}


Tablo 4 incelendiğinde öğrencilerin Covid-19 aşısına yönelik tutumları analiz sonucunda çevresinde Covid-19 hastası olmasına göre farklılık göstermediği görülmektedir. $\mathrm{Bu}$ analize göre çevresinde Covid-19 hastası olan öğrencilerin $(3,13 \pm 0,69)$ ve çevresinde Covid-19 hastas1 olmayan öğrencilerin $(2,95 \pm 0,62)$ Covid-19 aşısına yönelik tutum ortalamaları aynıdır, anlamlı bir farklılık yoktur $(\mathrm{t}=1,90, \mathrm{p}>0,05)$. Çevresinde Covid-19 hastası olan öğrencilerin Covid-19 aşısına yönelik tutumları istatistiksel olarak çevresinde Covid-19 hastası olmayan öğrencilere oranla aynı düzeyde olduğu tespit edilmiştir.

Tablo 4 incelendiğinde öğrencilerin Covid-19 kontrolü algısı t testi analizi sonucunda çevresinde Covid-19 hastası olmasına göre farklılık göstermediği görülmektedir. $\mathrm{Bu}$ analize göre çevresinde Covid-19 hastası olan öğrencilerin
$(2,82 \pm 0,55)$ ve çevresinde Covid-19 hastas1 olmayan öğrencilerin $(2,82 \pm 0,41)$ Covid-19 kontrolüne yönelik alg1 düzeyleri ortalamaları aynıdır, anlamlı düzeyde farklı değildir $(t=0,02, p>0,05)$. Çevresinde Covid19 hastası olan öğrencilerin Covid-19 kontrolü algıları çevresinde Covid-19 hastası olmayan öğrencilerle istatistiksel olarak aynı düzeyde olduğu tespit edilmiştir. Anlamlı farklılığın oluşmaması sebebi örneklemdeki kişilerin çevrelerinde hastalığın yaygın olarak görülmesi $\quad(n=236) \quad$ şeklinde açıklanabilir. Örneklemdeki kişilerin yaklaşık \%77,8'inin çevresinde Covid-19 tanısı konulan hastalar bulunmaktadır.

Tablo 5'te öğrencilerin COVID-19 aşısına yönelik olumlu, olumsuz tutum ve mikro, makro kontrol ve kontrol edilebilirlik düzeyleri bölümlerine göre anlamlı olarak farklılaşıp farklılaşmadığı grupların puan ortalamaları üzerinden test edilmiştir.

Tablo 5. Öğrencilerin Olumlu, Olumsuz Tutum ve Mikro, Makro Kontrol ve Kontrol Edilebilirlik Düzeylerinin Bölümlerine Göre Farklılığını İnceleyen T Testi

\begin{tabular}{|c|c|c|c|c|}
\hline Bölüm & $\mathbf{n}$ & Olumlu Tutum $\mathrm{X} \pm \mathrm{Sd}$ & $\mathbf{t}$ & $\mathbf{p}$ \\
\hline $\begin{array}{l}\text { Sağlık Yönetimi } \\
\text { İnsan Kaynakları } \\
\text { Yönetimi }\end{array}$ & $\begin{array}{l}169 \\
134\end{array}$ & $\begin{array}{l}3,10 \pm 0,91 \\
2,79 \pm 0,93\end{array}$ & 2,83 & $0,005^{*}$ \\
\hline Bölüm & $\mathbf{n}$ & $\begin{array}{l}\text { Olumsuz Tutum } \\
\mathrm{X} \pm \text { Sd }\end{array}$ & $\mathbf{t}$ & $\mathbf{p}$ \\
\hline $\begin{array}{l}\text { Sağlık Yönetimi } \\
\text { İnsan Kaynakları } \\
\text { Yönetimi }\end{array}$ & $\begin{array}{l}169 \\
134\end{array}$ & $\begin{array}{r}3,26 \pm 0,70 \\
2,12 \pm 0,66\end{array}$ & 1,72 & 0,087 \\
\hline Bölüm & $\mathbf{n}$ & $\begin{array}{l}\text { Mikro Kontrol } \\
\mathrm{X} \pm \text { Sd }\end{array}$ & $\mathbf{t}$ & $\mathbf{p}$ \\
\hline $\begin{array}{l}\text { Sağlık Yönetimi } \\
\text { İnsan Kaynakları } \\
\text { Yönetimi }\end{array}$ & $\begin{array}{l}169 \\
134\end{array}$ & $\begin{array}{l}2,89 \pm 0,73 \\
2,71 \pm 0,65\end{array}$ & 2,19 & $0,030^{*}$ \\
\hline Bölüm & $\mathbf{n}$ & $\begin{array}{l}\text { Makro Kontrol } \\
\mathbf{X} \pm \text { Sd }\end{array}$ & $\mathbf{t}$ & $\mathbf{p}$ \\
\hline $\begin{array}{l}\text { Sağlık Yönetimi } \\
\text { İnsan Kaynakları } \\
\text { Yönetimi }\end{array}$ & $\begin{array}{l}169 \\
134\end{array}$ & $\begin{array}{l}2,60 \pm 0,81 \\
2,27 \pm 0,80\end{array}$ & 3,53 & $\mathrm{p}<0,001 * *$ \\
\hline Bölüm & $\mathbf{n}$ & $\begin{array}{l}\text { Kontrol } \\
\text { Edilebilirlik } \mathrm{X} \pm \text { Sd }\end{array}$ & $\mathbf{t}$ & $\mathbf{p}$ \\
\hline $\begin{array}{l}\text { Sağlık Yönetimi } \\
\text { İnsan Kaynakları } \\
\text { Yönetimi }\end{array}$ & $\begin{array}{l}169 \\
134\end{array}$ & $\begin{array}{l}3,29 \pm 0,80 \\
3,05 \pm 0,74\end{array}$ & 2,66 & $0,008^{*}$ \\
\hline
\end{tabular}


Tablo 5 incelendiğinde öğrencilerin Covid-19 aşısına yönelik olumlu tutumları analiz sonucunda bölümüne göre farklılık gösterdiği görülmektedir. Analize göre Sağllk Yönetimi $(3,10 \pm 0,91)$ ve İnsan Kaynakları Yönetimi $(2,79 \pm 0,93)$ bölümü öğrencilerinin Covid-19 aşısına yönelik olumlu tutum ortalamaları birbirinden farklıdır $(\mathrm{t}=2,83, \mathrm{p}<0,05)$. Sağlık Yönetimi bölümü öğrencilerinin Covid-19 aşısına yönelik olumlu tutumları istatistiksel olarak İnsan Kaynakları Yönetimi bölümü öğrencilerinden daha yüksek olduğu bulunmuştur. Sağglık Yönetimi öğrencilerinin aşının etkisine olan güvenleri daha fazladır. $\mathrm{Bu}$ bilincin oluşmasındaki temel sebep sağlıkla ilgili durumlara daha fazla yatkın olmalarıdır. Toplumlarda koronavirüsün elimine edilmesi ve etkin bağışıklığın sağlanabilmesi aşıya karşı olumlu tutumların geliştirilmesi ile mümkündür. Yapılan bir araştırmada aşılama stratejilerinin başarısının, toplumların aşıların yararları ya da riskleri konusundaki algilarına ve aşılamaya duydukları güvene, olumlu tutumlara dayalı olduğunu ifade etmiştir. ${ }^{36}$

Tablo 5 incelendiğinde öğrencilerin Covid-19 aşısına yönelik olumsuz tutumları analiz sonucunda bölümüne göre farklılık göstermediği tespit edilmiştir. $\mathrm{Bu}$ analize göre Sağllk Yönetimi $(3,26 \pm 0,70)$ ve İnsan Kaynakları Yönetimi $(2,12 \pm 0,66)$ bölümü öğrencilerinin Covid-19 aşısına yönelik olumsuz tutum ortalamaları aynıdır. Aralarındaki fark anlamlı değildir $(\mathrm{t}=1,72$, $\mathrm{p}>0,05)$. Sağllk Yönetimi bölümü öğrencilerinin Covid-19 aşısına yönelik olumsuz tutumları istatistiksel olarak İnsan Kaynakları Yönetimi bölümü öğrencilerine oranla aynı düzeyde olduğu tespit edilmiştir. Her iki bölüm öğrencilerinin de aşıya yönelik olumsuzluk ifade eden görüşleri düşük seviyededir. İnsan Kaynakları Yönetimi bölümü öğrencilerinin bağışıklamaya yönelik bilgi düzeyleri artılır ise aşıya yönelik olumlu tutumlarının da bu doğrultuda yükselmesi beklenmektedir.

Tablo 5'e göre öğrencilerin Covid-19 kontrolüne yönelik mikro kontrol analiz sonucunda bölümüne göre farklılık gösterdiği görülmektedir. $\mathrm{Bu}$ analize göre Sağlık Yönetimi $(2,89 \pm 0,73)$ ve İnsan Kaynakları Yönetimi $(2,71 \pm 0,65)$ bölümü öğrencilerinin Covid-19 kontrolüne yönelik mikro kontrol düzeyleri ortalamaları birbirinden farklıdır $(\mathrm{t}=2,19, \mathrm{p}<0,05)$. Sağlık Yönetimi bölümü ögrencilerinin Covid-19 mikro kontrol ortalamaları istatistiksel olarak İnsan Kaynakları Yönetimi bölümü öğrencilerinden daha yüksek olduğu bulunmuştur. Sağlık Yönetimi bölümü öğrencilerinin kişisel tedbirlere bağlı olarak Covid-19 hastalığının kontrolünün sağlanabileceğine olan inançları daha fazladır. Sosyal paylaşım platformlarında yer alan maske, temizlik mesafe ve el hijyeni gibi çağrışımların toplumun her kesiminden bireylerde olduğu gibi, öğrenciler üzerinde de bir farkındalık oluşturduğu aşikardır. Alan yazında yapılan çalışmalara göre mikro (kişisel) önlemlerin salgının seyrini değiştirmede en önemli etken olduğu, bireylerin bu konuya uyum sağlama isteğinin olduğu ve medyanın özellikle kişisel temizlik ve sağlık bilgisi aktarımında önemli rol oynadığı ifade edilmiştir. ${ }^{37,} 38$ İngiltere, İskoçya ve Galler'de yapılan bir çalışmada domuz gribi salgınının bireylerin kişisel kontrolünde bir davranış değişikliği ortaya çıkarıp çıkarmadığı analiz edilmiştir. Araştırmaya göre örneklem grubundaki bireylerin \%28'i normalden daha fazla elini sabun ve su ile yıkadığını, \%17'si etrafındaki dokunabilir alanları dezenfekte etme sıklığının arttığını, \%35'i ise kalabalık ortamlardan kaçındığını ifade etmişlerdir. ${ }^{39}$

Tablo 5'e göre öğrencilerin Covid-19 kontrolüne yönelik makro kontrol düzeyleri analiz sonucunda bölümüne göre farklılık gösterdiği görülmektedir. $\mathrm{Bu}$ analize göre Sağlık Yönetimi $(2,60 \pm 0,81)$ ve İnsan Kaynakları Yönetimi $(2,27 \pm 0,80)$ bölümü öğrencilerinin Covid-19 kontrolüne yönelik makro kontrol düzeyleri ortalamaları birbirinden farklıdır $(\mathrm{t}=3,53, \mathrm{p}<0,001)$. Sağl1k Yönetimi bölümü öğrencilerinin Covid-19 makro kontrol ortalamaları istatistiksel olarak İnsan Kaynakları Yönetimi bölümü öğrencilerinden daha yüksek olduğu bulunmuştur. Sağlık Yönetimi ögrencilerinin kurumsal, ulusal ve küresel 
düzeyde alınan tedbirlerin etkililiğine olan inançları daha fazladır.

Tablo 5'e göre öğrencilerin Covid-19 kontrolüne yönelik kontrol edilebilirlik düzeyleri analiz sonucunda bölümüne göre farklılık gösterdiği görülmektedir. Bu analize göre Sağlık Yönetimi $(3,29 \pm 0,80)$ ve İnsan Kaynakları Yönetimi $(3,05 \pm 0,74)$ bölümü öğrencilerinin Covid-19 kontrolüne yönelik kontrol edilebilirlik düzeyleri ortalamaları birbirinden farklıdır $(t=2,66, p<0,05)$. Sağlik Yönetimi bölümü öğrencilerinin Covid-19 kontrol edilebilirlik ortalamaları istatistiksel olarak İnsan Kaynakları Yönetimi bölümü öğrencilerinden daha yüksek olduğu bulunmuştur.
Öğrencilerin Covid-19 kontrol algıları değerlendirildiğinde en yüksek ortalamaların kontrol edilebilirlik boyutunda yer aldığ1 görülmektedir. Her iki bölüm öğrencilerinin de Covid-19 hastalığının kontrol edilebileceğine olan inançları yüksektir. Çin'de yapılan bir araştırma da Covid-19 hastalığının ortaya çıkması birey ve toplumda yoğun olarak olumsuz davranışlara ve tepkilere yol açmadiğ 1 ifade edilmiştir. Bilakis toplum genelinde saldirganlık ve sigara içme gibi olumsuz davranışların da azaldığ1 tespit edilmiştir. $\mathrm{Bu}$ minvalde bireylerin ve toplumların alınan hayati tedbirler ile birlikte hastalığın kontrol edilebilirliğine olan inançları yüksektir. ${ }^{40}$

\section{SONUÇ VE ÖNERILER}

Günümüzde yapılan birçok aşı çalışması, topluma yönelik koruyucu önlemlerin alınması ve uygulamaya konulması, hükümet politikaları ve düzenlemelerin hepsi uzun vadede koronavirüs pandemisinin yıkıcı etkisini azaltmaya yönelik girişimlerdir. $\mathrm{Bu}$ tür girişimler sayesinde salgın hastalıkların toplumlara vereceği zararlar azaltılabilir. Toplumun genelinde benimsenen uygulanabilir aşı politikaları ile güçlü bir koruyucu sağlik hizmeti alt yapısı oluşturularak bağışıklama sağlanabilir. Bu durum ülkelerin sağlık sistemi etkinliğini optimal seviyelere çıkarabilir.

Așılama en nihayetinde bağışıklama hizmetlerinin temel yapı taşını oluşturan bir sağlık hizmetidir ve önemli bir halk sağlığı uygulamasıdır. Birçok salgın hastalıkta olduğu gibi günümüz pandemisinde de aşılama hastalıktan korunmak, toplum bağışıklığını artırmak, ölüm oranlarını düşürmek ve yıkıcı etkinin azaltılmasını sağlamak için en etkili, güvenli, ekonomik ve rasyonel bir çözüm yoludur.

İçinde bulunduğumuz dönemde de sağlik sistemimizin ayakta kalabilmesi ve ihtiyaçlara yeterli düzeyde hızlı ve sürdürülebilir olarak cevap verebilmesi için bağışıklama hizmetlerinin aksamaya uğramadan devam ettirilmesi elzemdir. Aşılama politikalarının başarısı, birey ve toplumların aşıların faydaları ya da olası riskleri hakkındaki algılarına ve aşılamaya duydukları güvene göre değişmektedir. $\mathrm{Bu}$ doğrultuda toplum genelinde oluşan aş1 karşıtı yaklaşımların elimine edilmesi gerekir.

Çalışmada da öğrencilerin bölümlerine göre hem aşıya yönelik tutum hem de kontrol algıları noktasında anlamlı düzeyde farklılık olduğu bilinmektedir. Ayrıca sağlık eğitimi alan bireylerin hem Covid-19'un kontrolüne hem de aşısına yönelik olumlu tutumları anlamlı düzeyde daha fazla çıkmaktadır. İnsan Kaynakları Yönetimi bölümü öğrencilerinin hastalığa karşı bilincinin artırılması ve aşılama karşıtı tutumlarının köreltilmesi için sağl1k bilgisine olan ihtiyacı aşikardır. Üniversitelere ve akademisyenlere bu yolda ciddi görevler düşmektedir. İnsan Kaynakları Yönetimi müfredatına sağlık bilgisi ve hastalık yönetimi ile ilgili dersler eklenebilir. Öğrenciler için bağışıklamaya yönelik eğitim, sempozyum ve paneller düzenlenebilir. Bunlar yardımıyla aşılamaya karșı asılsız bilgi kirliliği ortadan kaldırılmalı ve öğrenciler aşılamaya özendirilmelidir.

Bir toplumun sağlı düzeyinin yükseltebilmesi ancak toplumda yaşayan kişilerin bu konuda sorumluluğu paylaşması ve birbirlerini desteklemesi ile mümkündür. Şüphesiz ki aşılama ve bağışıklama ile ilgili 
yapılan bilimsel çalışmalar toplumdaki güveni artırmaya fayda sağlayacaktır.

Yapılan bu çalışma ile elde edilen verilerin gelecekte öğrencilerin aşıya yönelik algılarının değerlendirildiği, aşı karşıtlı̆̆ durumunun incelendiği ve elimine edilmesine yönelik çözüm önerilerinin araştırılacağı başka çalışmalara zemin hazırlaması ve diğer araştırmalara referans olması beklenmektedir.

\section{KAYNAKLAR}

1. Ekiz, T, Ilıman E. ve Dönmez, E. (2020). "Bireylerin Sağlık Anksiyetesi Düzeyleri ile Covid-19 Salgını Kontrol Algısının Karşılaştırılması". Uluslararası Sağlık Yönetimi ve Stratejileri Araştırma Dergisi, 6 (1), 139-154.

2. Worldometers. (2021). "Covid-19 Coronavirus Pandemic", Erișim adresi: https://www.worldometers.info/coronavirus/ (Erişim tarihi: 30 Kasım 2020).

3. ILO. Uluslararası Çalışma Örgütü. (2021). Uluslararası Çalışma Örgütü. Erişim adresi: https://www.ilo.org/ (Erişim tarihi: 9 Ocak 2021)

4. Kutlu, H.H. ve Altındiş, M. (2018). "Aș1 karșıtlığı". Flora Dergisi, 23 (2), 47-58.

5. Keskin, F. (2020). "Covid-19 Pandemisinde Așılanmanın Önemi”. Erişim adresi: https://www.ido.org.tr/userfiles/files/ Covid_19Pandemisinde_asilanma.pdf (Erișim tarihi: 14 Mart 2021)

6. Yiğit, T, Oktay, B.Ö, Özdemir, C.N. ve Moustafa Pașa, S (2020). "Aşı Karşıtlığı ve Fikri Gelişimi". Journal of Social and Humanities Sciences Research, 7 (53), 1244-1261.

7. Bozkurt, H.B. (2018). "Aşı Reddine Genel Bir Bakış ve Literatürün Gözden Geçirilmesi". Kafkas Tıp Bilimleri Dergisi, $8(1), 71-76$

8. Ataç, Ö. ve Aker, A.A. (2014). "Așı Karșıtllı̆̆ı". Sağlık Düşüncesi ve Tıp Kültürü Dergisi, 30 (1), 42-47.

9. Erkekoğlu, P, Köse, S.B.E, Balcı, A. ve Yirün, A. (2020). "Aşı Kararsızlığı ve COVID-19'un Etkileri". Literatür Eczacılık Bilimleri Dergisi, 9 (2), 208-220.

10. Küçük, S. (2020). Tarihte Salgın Hastalıklar. Ankara: Türk Yurdu.

11. Parıldar, H. ve Dikici, M.F. (2020). "Pandemiler Tarihi". Klinik Tıp Aile Hekimliği, 12 (1), 1-8.

12. Lepan, N. (2020). "Visualizing the History of Pandemics" Erişim adresi: https://www.visualcapitalist.com/history-ofpandemics-deadliest/. (Erișim Tarihi: 14 Mart 2020).

13. Oğurlu, E. (2020). "Tarih Boyunca Pandemiler ve Uluslararası Sisteme Etkileri". Electronic Turkish Studies, 15 (4), 791-805.

14. T.C Sağlık Bakanlığı. (2020). "Türkiye'de Aşının Tarihçesi", Erişim adresi: https://asi.saglik.gov.tr/genel-bilgiler/33a\%C5\%9F\%C4\%B1n\%C4\%B1n-tarih\%C3\%A7esi.html. (Erişim Tarihi: 11 Şubat 2021).
15. T.C Sağlık Bakanlığı. (2020). "Așı Nedir, Nasıl Etki Eder?". Erişim adresi: https://asi.saglik.gov.tr/genel-bilgiler/49a\%C5\%9F\%C4\%B1-nedir,-nas\%C4\%B11-etki-eder.html. (Erişim Tarihi: 11 Şubat 2021).

16. Altındiş, M. ve Kutlu, H.H. (2017). “Artan Aşı Karşıtllı̆̆ Eğilimi; Nedenleri ve Sonuçları". Sağlık Düşüncesi ve Tıp Kültürü Dergisi, 45 (1), 82-87.

17. Riedel, S. (2005). "Edward Jenner and The History Of Smallpox and Vaccination". Baylor University Medical Center Proceedings, 18 (1), 21-25.

18. Hilleman, M.R. (2000). "Vaccines in Historic Evolution and Perspective: A Narrative Of Vaccine Discoveries". Vaccine, 18 (15), 1436-1447.

19. Türk Tabipleri Birliği. (2020). "Tarihten Öğrenecek Çok Şey Var”. Erişim adresi: https://www.ttb.org.tr/eweb/asi_ brosur/tarih.htm. (Erişim Tarihi: 11 Şubat 2021).

20. Eskiocak, M. ve Marangoz, B. (2019). "Türkiye'de Bağıșılama Hizmetlerinin Durumu". Ankara: Türk Tabipleri Birliği Yayınları.

21. World Health Organization. (2020). "Vaccines and Immunization". Erişim adresi: https://www.who.int/healthtopics/vaccines-and-immunization\#tab=tab_1. (Erişim Tarihi: 11 Şubat 2021).

22. T.C Sağlık Bakanlığı. (2020). “Aşının Yararları”. Erişim adresi: https://asi.saglik.gov.tr/genel-bilgiler/27$\% \mathrm{C} 5 \% 9 \mathrm{~F} \% \mathrm{C} 4 \% \mathrm{~B} 1 \mathrm{n} \% \mathrm{C} 4 \% \mathrm{~B} 1 \mathrm{n}$-yararlar\%C4\%B1.html. (Erişim Tarihi: 14 Mart 2021.)

23. Yüksel, G.H. ve Topuzoğlu, A. (2019). “Aș1 Redlerinin Artması ve Aşı Karşıtlığını Etkileyen Faktörler”. ESTÜDAM Halk Sağlığı Dergisi, 4 (2), 244-258.

24. MacDonald, N.E. (2015). "Vaccine Hesitancy: Definition, Scope and Determinants". Vaccine, 33 (34), 4161-4164.

25. Düzgün, M.V. ve Dalgıç, A.İ. (2019). "Toplum Sağlığı İçin Giderek Artan Tehlike Așı Reddi Önlenebilir Mi?’. Güncel Pediatri, 17 (3), 424-434.

26. Gür, E. (2019). "Așı Kararsızlığı-Așı Reddi”. Türk Pediatri Arşivi, 54 (1), 1-2.

27. Kahraman, S. ve Kaplan, F. (2020). “Türkiye'de Kızamık Hastalığının Son Yıllarda Artma Nedenleri”. Bandırma Onyedi Eylül Üniversitesi Sağlık Bilimleri ve Araştırmaları Dergisi, 2 (3), 175-183 
28. Çıtak, G. ve Aksoy, Ö.D. (2021). “Așılamada Önemli Bir Engel: Aşı Reddi”. ERÜ Sağlık Bilimleri Fakültesi Dergisi, 7 (2), 15-20.

29. Eskola, J, Duclos, P, Schuster, M. ve MacDonald, N.E. (2015) "How To Deal With Vaccine Hesitancy?". Vaccine, 33 (34), 4215-4217.

30. Argüt, N, Yetim, A. ve Gökçay, G. (2016). “Așı Kabulünü Etkileyen Faktörler”. Çocuk Dergisi, 16 (1), 16-24.

31. Geniş, B, Gürhan, N, Koç, M, Geniş, Ç, Şirin, B, Çırakoğlu, O.C. ve Coşar, B. (2020). "Development of Perception and Attitude Scales Related With Covid-19 Pandemia". Pearson Journal of Social Sciences ve Humanities, 5 (7), 306-326.

32. Özsarı, S.H. (2013). "Sağlık Yönetimi ve Sağlık Eğitimi İlişkisi”. Yükseköğretim Dergisi, 3 (1), 9-11.

33. Tutku, E, Ilıman, E. ve Dönmez, E. (2020). "Bireylerin Sağlık Anksiyetesi Düzeyleri ile Covid-19 Salgını Kontrol Algısının Karşılaştırılması". Uluslararası Sağlık Yönetimi ve Stratejileri Araştırma Dergisi, 6 (1), 139-154.

34. Akbal, E. ve Gökler, M.E. (2020). "Covid-19 Salgını Sürecinde Eksikliği Ortaya Çıkan Bir Gerçek: Sağlık Okuryazarlığı". Estüdam Halk Sağlığı Dergisi, (5), 154-161.

35. Üzüm, Ö, Eliaçık, K, Örsdemir, H.H. ve Öncel, E.K. (2019) "Ebeveynlerin aşı yaklaşımlarını etkileyen faktörler: Bir eğitim araştırma hastanesine ilişkin değerlendirme”. Çocuk Enfeksiyon Dergisi, 13 (3), 144-149.

36. Kutlu, H.H. ve Altındiş, M. (2018). "Aşı Karşıtllı̆ı̆”. Flora Dergisi, 23 (2), 47-58.

37. Kwok, K, O, Li, K.K, Chan, H.H, Yi, Y.Y, Tang, A, Wei, W.I and Wong, S.Y.S. (2020). "Community Responses During The Early Phase of The COVID-19 Epidemic in Hong Kong: Risk Perception, İnformation Exposure and Preventive Measures". Emerg Infect Dis, 26/7), 1575-1579.

38. Bostan, S, Erdem, R, Öztürk, Y.E, Kılıç, T. and Yılmaz, A (2020). "The Effect of COVID-19 Pandemic on the Turkish Society”. Electronic Journal of General Medicine, 17 (6), 1-8.

39. Rubin, G.J, Amlôt, R, Page, L. and Wessely, S. (2009). "Public Perceptions, Anxiety, and Behaviour Change in Relation To The Swine Flu Outbreak: Cross Sectional Telephone Survey". BMJ, 339

40. Li, J.B, Yang, A, Dou, K, Wang, L.X, Zhang, M.C. and Lin, X (2020). "Chinese Public's Knowledge, Perceived Severity, and Perceived Controllability of The COVID-19 and Their Associations With Emotional And Behavioural Reactions, Social Participation and Precautionary Behaviour: A National Survey". doi:10.31234/osf.io/5tmsh 